\title{
Dengue Virus Transmission during Outbreak within Endemic Area in Indonesia : A Spatial and Temporal Analysis \\ By SULISTYAWATI
}


Wijayanti et al (2019): Dengue virus transmission December 2019 Vol.11

\title{
Dengue Virus Transmission during Outbreak within Endemic Area in Indonesia : A Spatial and Temporal Analysis
}

\author{
Siwi Pramatama Mars Wijayanti ${ }^{1)} *$, Sri Nurlaela ${ }^{1)}$, Devi Octaviana ${ }^{1)}$, Fuando Alfatihana Putra ${ }^{1)}$, \\ $17 \quad$ Siti Nurhayati ${ }^{1)}$, Sulistyawati Sulistyawati ${ }^{2)}$ \\ ${ }^{1)}$ Department of Public Health, Faculty of Health Sciences, University of Jenderal Soedirman \\ 2) Department of Public Health, Universitas Ahmad Dahlan, Yogyakarta, Indonesia
}

\begin{abstract}
*Corresponding author: Siwi Pramatama MarsWijayanti, B Building Public Health Department, Faculty of Health Sciences, University of Jenderal Soedirman. Jl.Dr. Soeparno, Karangwangkal, Purwokerto, Indonesia. Email : siwimars@gmail.com
\end{abstract}

\begin{abstract}
Continous surveillance of DENV tranmission pattern is undoubtedly important to provide a proper input to the dengue prevention and control programme. However, the DENV transmission pattern in outbreak event is still under research. This study interested to analyse the spatio temporal distribution of dengue cases in the area of study, particularly during outbreak event. Coordinate of 404 cases from 2016 outbreak in Banyumas Regency, Indonesia were collected by GPS $78 \mathrm{~S}$ with Viewranger/Maverick application. Two clusters area were identified during outbreak, and the initial place of outbreak is surprisingly occured in the border area, assuming that human movement and imported cases may play role in outbreak event. The distribution pattern of outbreak is clustered, as consequence of limited flight range of Aedes sp mosquito, high density population and rainfall. Information from our study highlighted where and when public health resources should be concentrated.
\end{abstract}

Key words: dengue, virus, transmission, spatial, temporary, analysis How to cite this article: WijayantiSPM, Nurlaela S, et al (2019): Dengue virus transmission during outbreaks within endemic area in Indonesia: A spatial and temporal analysis, Ann Trop \& Public Health; 22(11): S320. DOI: $\underline{\text { http://doi.org/10.36295/ASRO.2019.221122 }}$

\section{INTRODUCTION}

Dengue disease is still become a major public health problem, particularly in tropical regions due to the abudance of its vector, Aedes aegypti and Aedes albopictus ${ }^{1,2}$.It is caused by Dengue Virus (DENV), genus Flavivirus (family Flaviviridae), which consisted of 5 serotypes (DENV-1, 2, 3, 4 and 5) ${ }^{3}$. DENV infection mostly as ymptomatic, however several cases could lead to severe disease such as Dengue Haemmorrhagic Fever (DHF) and Dengue Shock Syndrome (DSS) ${ }^{4.5}$. The spread of DENV infection drives by its transmission vector, mosquito Aedes aegypti as main vector and Aedes albopictus as secondary vector ${ }^{2}$. There is a current need to provide effective preventive for DENV infection since this virus expands not only in tropical countries but also currently in non tropical countries due the spread of Ae.albopictus ${ }^{6}$.Dengue is highly endemic in Indonesia and still become one of the main health problems in this country since it was detected in the cities of Jakarta and Surabaya in $1968^{7}$. Although the case fatality rate (CFR) of DENV infection is declining but reports illustrated that among countries in Southeast Asia, Indonesia has the highest economic burden of dengue ${ }^{8,9}$. Spatial distribution of DENV infection could be influenced by several factors such as uncontrolled urbanization, human

8 
Wijayanti et al (2019): Dengue virus transmission December 2019 Vol.11

mobility, climatic changes, and socioeconomy factors ${ }^{10-12}$. In Indonesia, prevention and control efforts currently focus on reducing the number of mosquito populations by several approaches ranging from larvacides until genetic mosquito modifications ${ }^{13}$. However, despite local authorities spend around 6.75 million US\$to control vector populations, Indonesia have seen a drastic increase in the number of cases since $2011^{14}$, therefore calling for novel strategies to control the transmission of dengue in the country. The epidemiology of dengue disease change overtime, following the change in its vector bionomic, enviromental changes, land use and other demographical tranformation ${ }^{15}$. Those facts causes the change DENV transmission pattern in several areas ${ }^{16-}$ ${ }^{18}$. Continous surveillance about the DENV tranmission pattern is indeed important to provide a proper input to the dengue prevention and control programme. However, the DENV transmission in dengue outbreak event is still under research. This information is crucial for dengue outbreak preparedness, particularly in dengue endemic area. In recent years, the utilisation of geographical information system (GIS), a computerized system that combines spatial and descriptive data for mapping and analysis is being increasingly used to collate and map available epidemiological information ${ }^{19}$. This advanced analytical tool has been widely used in disease surveillance and monitoring, identification of high-risk diseases affected areas, prioritize areas for mitigation and surveillance plan, programming and monitoring the incidence record, providing an effective tool for visualization and spatial analysis of epidemiology data and environmental exposure ${ }^{20,21}$. It is indeed interesting to analyse the spread of dengue cases in the event of dengue outbreak using GIS. In 2016, in Banyumas Regency, Central Java Indonesia had a devastating outbreak from 14 February to 30 March 2016, with 536 of dengue cases with 11 people died. This study interested to analyse the spatio temporal distribution of dengue cases in the area of study, particularly during outbreak event. This information will provide valuable input to the health authorization to prevent dengue outbreak in endemic area.

\section{SUBJECT AND METHODS}

\section{Ethical statement}

This study was carried out with ethical approval from Ministry of National Education, Faculty of Medicine University of Jenderal Soedirman REF 145/KEPK.VII/2016

\section{Study area}

The study area in this study is surrounding of capital town of Purwokerto in Banyumas Regency. This regency located in the southwest of Central Java Province, Indonesia. Coordinates for this location are as follows: 108" $39^{\prime} 17^{\prime \prime}-109^{\prime \prime} 27$ 15" East longitude, and $37^{\prime \prime} 15^{\prime} 05^{\prime \prime}-7 " 37 \times 17^{\prime \prime}$ South latitude. This area of study showedhigh risk of dengue infection reported during the period 2000 to 2013, around $1 / 3$ of the total number of cases(1250/3810) recorded in this regency. Purwokerto, capital town of Banyumas regency showed high proportion of high socio-economic with 4 hospitals.

\section{Data Collection and Analysis}

Patient data was collected from Banyumas Regency Office. The official number of dengue cases during outbreak were 536, however only 464 patient were included in this study due to the complete information. GPS coordinates points were collected from all 464 patients in the regency using GPS $78 \mathrm{~S}$ with Viewranger/Maverick application. Validity and reliability of GPS testwas conducted by calibration technique. Data was analysis using overlay technique spatial analysis, consist of analysis of point pattern method that is 
Wijayanti et al (2019): Dengue virus transmission December 2019 Vol.11

elementary analysis of disease, Nearest Neighbour Index (NNI), Convex hulls and Cluster Analysis of illness date with SatScan softwere.

\section{RESULTS}

The study area, Banyumas Regency, experienced a regular dengue cases every year, with several outbreak happened in 2008, 2010, 2013 and 2016. In 2016, this area undergo the most devastating outbreak with 990 cases during a year. The detail of dengue cases fluctuation from 2002 to 2016 can be seen in Figure 1 .

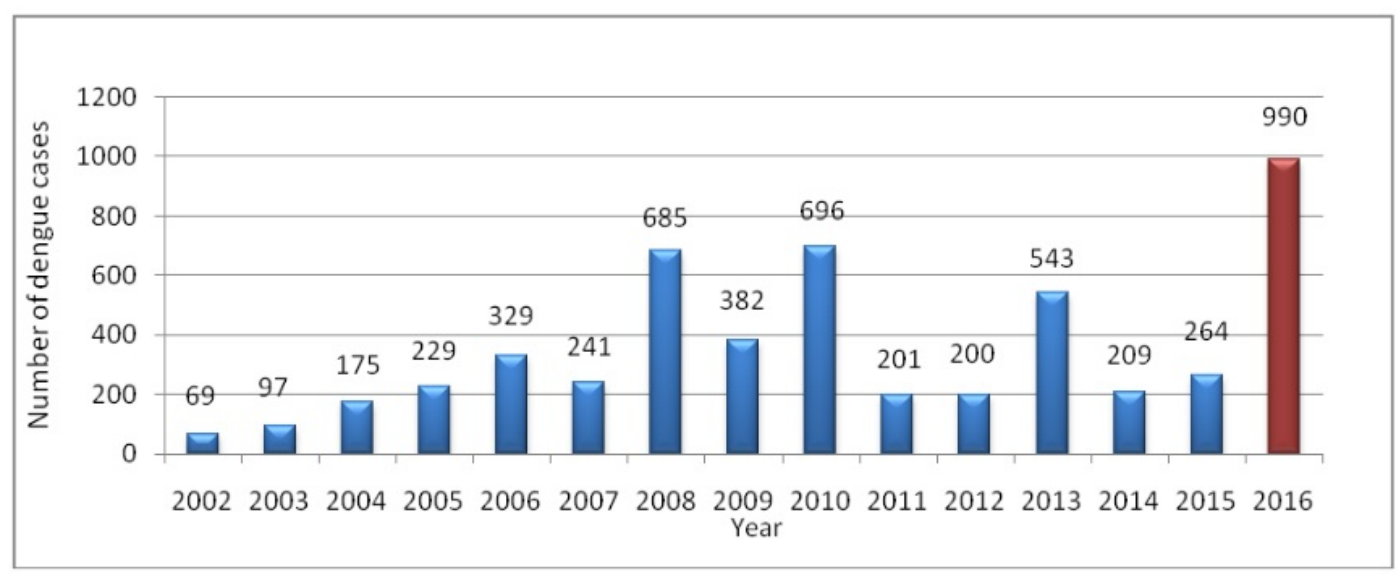

Figure 1. Fluctuation of dengue cases in Banyumas Regency from 2002-2016.

The dengue outbreak period was happened from 14 February to 30 March 2016 with 536 dengue cases with 11 died. The spread of disease can be seen in Figure 2.

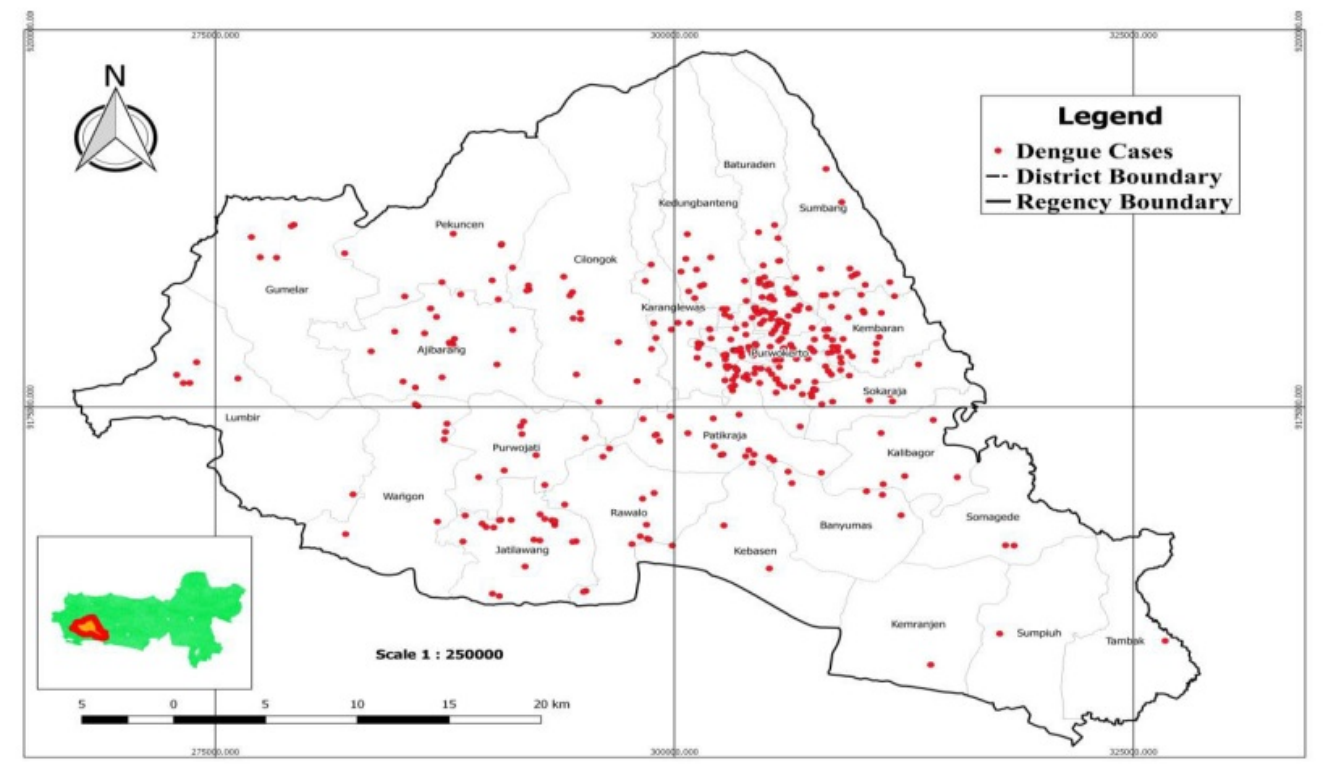

8

¡A Annals of Tropical Medicine \& Public Health S320 


\section{Wijayanti et al (2019): Dengue virus transmission December 2019 Vol.11}

Figure 2. The spread of dengue cases during outbreak in Banyumas Regency 2016

Distribution pattern of DHF outbreaks was analysed by calculating the nearest neighboring distance index or Nearest Neighbour Index (NNI) obtained through Quantum GIS software .

Table 1. Distribution pattern of dengue outbreak in Banyumas Regency 2016

\begin{tabular}{cc}
\hline \multirow{2}{*}{ Parameter } & Year \\
\cline { 2 - 2 } & 2016 \\
\hline Area $\left(\mathrm{m}^{2}\right)$ & $1.134 .154,210$ \\
Number of cases & 436 \\
Cases & 404.00 \\
NNI & 0.54052409 \\
Distribution pattern & Clustered \\
\hline
\end{tabular}

The spread of DHF cases extends to almost all sub districts in Banyumas District, with details as illustrated in the map in Figure 3.

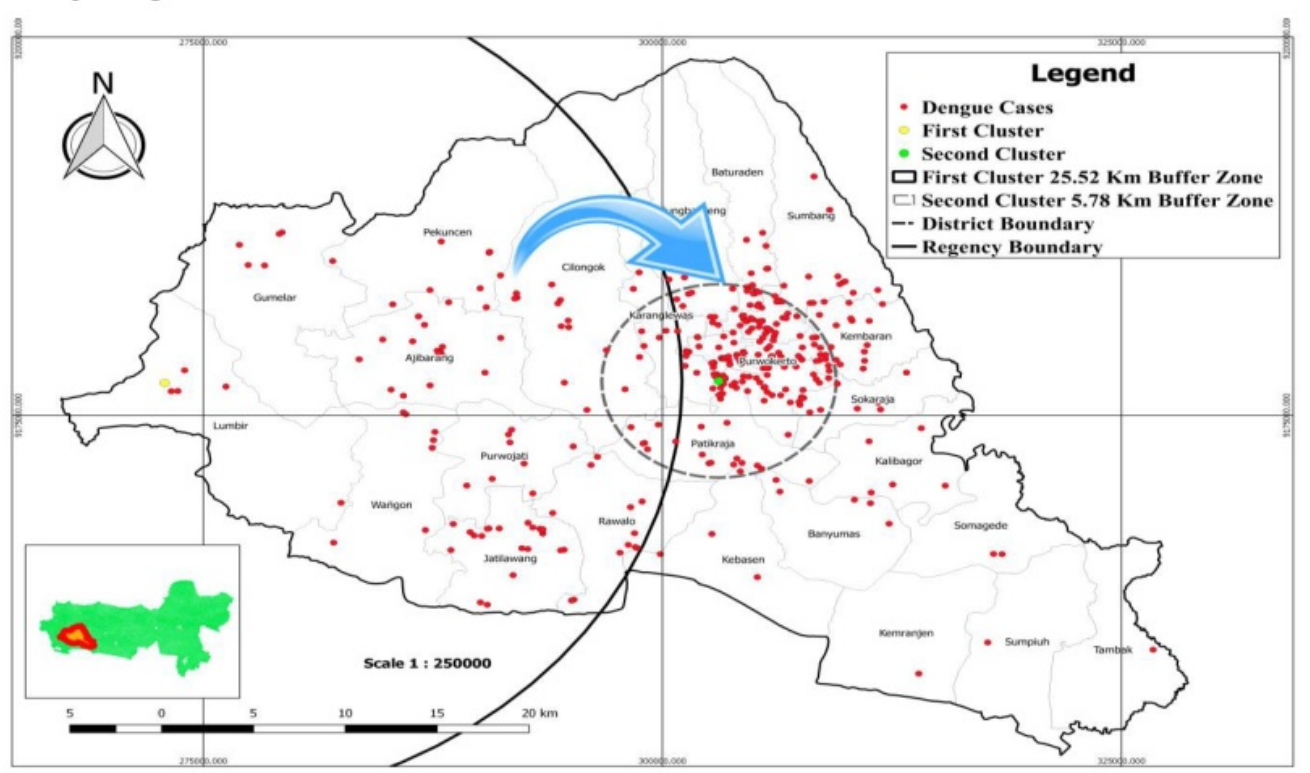

Figure 3. Movement from first cluster and second cluster during dengue outbreak 2016.

Based on Figure 3, the wide spread of dengue outbreak in Banyumas Regency in 2016 was 1,134,154,210 $\mathrm{m} 2$.Based on the results of the analysis analysis using space time permutation on the software SatScan showed the existence of 2 clusters cases of dengue outbreaks. The first cluster in Lumbir, Ajibarang, Wangon and surrounding areas with 99 cases occurring during 1-29 February 2016 with a radius of $25.52 \mathrm{~km}$ (p-value = 0.000 ) and the second cluster in Purwokerto City, Karanglewas and surrounding areas with the number of cases 190 that occurred on the period of 1-31 March 2016 with a radius of $5.78 \mathrm{~km}$ (p-value $=0.000$ ).

(C)Annals of Tropical Medicine \& Public Health S320 
Wijayanti et al (2019): Dengue virus transmission December 2019 Vol.11

Table 2. Spatial clustering of dengue outbreak based on the date of illness

\begin{tabular}{llllllll}
\hline No & Area & $\begin{array}{l}\text { Radius } \\
(\mathrm{Km})\end{array}$ & Beginning & End & Observed & Expected & $p$-value \\
\hline 1 & $\begin{array}{l}\text { Sub district } \\
\text { Lumbir, Gumelar, }\end{array}$ & 25,52 & $1-2-2016$ & $29-2-2016$ & 3,62 & 27,36 & 0.000 \\
& $\begin{array}{l}\text { Ajibarang, } \\
\text { Wangon, } \\
\text { Jatilawang, }\end{array}$ & & & & & \\
& $\begin{array}{l}\text { Pekuncen, } \\
\text { Cilongok }\end{array}$ & & & & & \\
2 & $\begin{array}{l}\text { Purwokerto, } \\
\text { Karanglewas, } \\
\text { Patikraja, } \\
\text { Kedungbanteng }\end{array}$ & 5,78 & $1-3-2016$ & $31-3-2016$ & 1,38 & 137,50 & 0.000 \\
\hline
\end{tabular}

\section{DISCUSSION}

Dengue outbreak in Banyumas Regency affected to almost all areas within the district, spread over 1.134.154. $210 \mathrm{~m}$ of area in Banyumas regency, and caused 536 of dengue cases with 11 people died. Based on space time permutation analysis, there are two clusters during outbreak 2016 which interesting to be observed. The first cluster located in west part of Banyumas regency (Lumbir, Ajibarang, Wangon) which occured during 1-29 February 2016 within a radius of $25.52 \mathrm{~km}$. The second cluster was happened in the capital of regency (Purwokerto) and its surrounding areas on the period of 1-31 March 2016 within a radius of $5.78 \mathrm{~km}$. Surprisingly, the outbreak initially emerged in the east area of Regency, and then moved spread to Purwokerto, capital city of regency. Since 2000, a high number of dengue cases was clustered in Purwokerto as the most endemic area of dengue in the regency ${ }^{10,22}$. It is interesting that in outbreak event, other areas of the regency turn out as the initial place of outbreak. The first cluster located in border area of regency, near Cilacap regency which known as industrial area. And then, the movements into high-risk areas (capital of regency) lead to individual infection, and local transmissionestablished when infected individuals return to their homes where aedes vectors abundant. The human mobility betwen people in the border area could be an explanation behind the initial event of oubreak. Several studies believes that human mobility as an important driver of DENV tranmission ${ }^{12,23}$. Dynamic human travel had stronger affects to the spread of DENV infection than the mobility of Aedes sp $p^{24}$. This is possibly a consequence of a short distance of the flight range of primary vector of dengue, Aedes aegypt ${ }^{25-27}$.The limited flight range of Aedes $s p$ also could explain the clustered pattern of DENV transmission both space and time ${ }^{28,29}$. As we found in this study based on NNI, the distribution pattern of DENV transmission in the area of study during outbreak is clustered. This results is also observed in the several studies of dengue transmission ${ }^{21,29}$. A complex immune interactions among the circulating serotypes in certain area, could cause temporal and spatial patterns of infection ${ }^{30,31}$. Unfortunately, there is no information about serotypes of dengue virus during outbreak. 
Wijayanti et al (2019): Dengue virus transmission December 2019 Vol.11

Between two clusters of epidemic in the area of study, the second cluster (Purwokerto) had more devastating effect (190 cases) than the first cluster ( 99 cases). This is suggested that at the second location it is more favorable for the spread of dengue cases, because it causes more cases, with a closer radius between cases. The case radius is also closer to the first cluster $(5.78 \mathrm{~km})$ compared to the second cluster $(25.52 \mathrm{~km})$. This might be explained by the demographical condition of second cluster (Purwokerto) which is urban, high population density and rainfall (Supplementary1). The risk of dengue was higher in urban area largerly explained by high population density, households with water storage container as mosquito breeding sites, and high rainfall $\frac{32.33}{7}$. Several previous studies believes that there is relationship between rainfall and dengue outbreaks ${ }^{34-36}$. High rainfall combined with high temperatures resulted high humidity which associated with higher feeding activity, development and survival of $A$. aegypti ${ }^{37,38}$.

The initial event of outbreak which happened in outside of "hotspot" area of dengue is a crucial information for the dengue prevention and control program. The risk of human mobility in border area or imported cases should 6 addressed. The possibility of imported cases also should be considered. In several cases of dengue outbreak, the early date of the first imported and locally transmitted case was mostly responsible for the outbreak ${ }^{39,40}$. By identifying spatial cluster of dengue cases in_endemic area is essential for planning and preparedness of dengue control. Two cluster area were identified in this study will help local health instutions to plan suitable interventions for dengue disease. Information from our study highlighted where and when public health resources should be concentrated. In addition, our study suggested that besides the "hotspot" area we need to aware other areas with high risk of imported cases such as border area.

\section{ACKNOWLEDGEMENT}

We gratefully acknowledge Banyumas Regency Office for their cooperation during data collection, all of the student who help with GPS coordinate collection and University of Jenderal Soedirman for the funding.

\section{REFERENCES}

1. Hasan S, Jamdar SF, Alalowi M, Al Ageel Al Beaiji SM. Dengue virus: A global human threat: Review of literature. Journal of International Society of Preventive \& Community Dentistry 2016; 6(1): 1-6.

2. Higa Y. Dengue Vectors and their Spatial Distribution. Tropical Medicine and Health 2011;39(4 Suppl): 17-27.

3. Mustafa MS, Rasotgi V, Jain S, Gupta V. Discovery of fifth serotype of dengue virus (DENV-5): A new public health dilemma in dengue control. Medical Journal, Armed Forces India 2015; 71(1): 67-70.

4. Duong V, Lambrechts L, Paul RE, et al. Asymptomatic humans transmit dengue virus to mosquitoes. Proceedings of the National Academy of Sciences of the United States of America 2015; 112(47): 14688-93.

5. Diamond MS, Pierson TC. Molecular Insight into Dengue Virus Pathogenesis and Its Implications for Disease Control, Cell 2015; 162(3): 488-92.

6. Messina JP, Brady OJ, Scott TW, et al. Global spread of dengue virus types: mapping the 70 year history. Trends in Microbiology 2014; 22(3): 138-46.

7. Sumarmo. Dengue haemorrhagic fever in Indonesia. The Southeast Asian journal of tropical medicine and public health 1987; 18(3): 269-74.

8. Pasteur S. Dengue in Indonesia. 2016. http://asia.dengue.info/sites/default/files/factsheet dengue in indonesia.pdf (accessed 19 october 2016).

9. Bhatt S, Gething PW, Brady OJ, et al. The global distribution and burden of dengue. Nature 2013; 496(7446): 504-7.

10. Wijayanti SPM, Porphyre T, Chase-Topping M, et al. The Importance of Socio-Economic Versus Environmental Risk Factors for Reported Dengue Cases in Java, Indonesia. PLOS Neglected Tropical Diseases 2016; 10(9): e0004964.

11. Gubler DJ. Dengue, Urbanization and Globalization: The Unholy Trinity of the 21(st) Century. Tropical Medicine and Health 2011; 39(4 Suppl): 3-11.

12. Wesolowski A, Qureshi T, Boni MF, et al. Impact of human mobility on the emergence of dengue epidemics in Pakistan. Proceedings of the National Academy of Sciences of the United States of America 2015; 112(38): 11887-92.

13. WHO. Global Strategy for Control and Prevention. 2012.

14. Stahl H-C, Butenschoen VM, Tran HT, et al. Cost of dengue outbreaks: literature review and country case studies. BMC Public Health 2013; 13(1): 1048. 
Wijayanti et al (2019): Dengue virus transmission December 2019 Vol.11

15. Siraj AS, Oidtman RJ, Huber JH, et al. Temperature modulates dengue virus epidemic growth rates through its effects on reproduction numbers and generation intervals. PLoS Negl Trop Dis 2017; 11(7): e0005797.

16. Ebi KL, Nealon J. Dengue in a changing climate. Environmental Research 2016; 151(Supplement C): 115-23.

17. Lozano-Fuentes S, Hayden MH, Welsh-Rodriguez C, et al. The Dengue Virus Mosquito Vector Aedes aegypti at High Elevation in México. The American Journal of Tropical Medicine and Hygiene 2012; 87(5): 902-9.

18. Haider Z, Ahmad FZ, Mahmood A, et al. Dengue fever in Pakistan: a paradigm shift; changing epidemiology and clinical patterns. Perspectives in Public Health 2015; 135(6): 294-8.

19. Aziz S, Ngui R, Lim YA, et al. Spatial pattern of 2009 dengue distribution in Kuala Lumpur using GIS application. Tropical biomedicine 2012; 29(1): 113-20.

20. Chu HJ, Chan TC, Jao FJ. GIS-aided planning of insecticide spraying to control dengue transmission. International journal of health geographics $2013 ; \mathbf{1 2}: 42$.

21. Wang C, Yang W, Fan J, Wang F, Jiang B, Liu Q. Spatial and temporal patterns of dengue in Guangdong province of China. Asia-Pacific journal of public health 2015; 27(2): Np844-53.

22. Wijayanti SPM, Sunaryo S, Suprihatin S, et al. Dengue in Java, Indonesia: Relevance of Mosquito Indices as Risk Predictors. PLOS Neglected Tropical Diseases 2016; 10(3): e0004500.

23. Falcón-Lezama JA, Santos-Luna R, Román-Pérez S, et al. Analysis of spatial mobility in subjects from a Dengue endemic urban locality in Morelos State, Mexico. PLOS ONE 2017; 12(2): e0172313.

24. Barmak DH, Dorso CO, Otero M. Modelling dengue epidemic spreading with human mobility. Physica A: Statistical Mechanics and its Applications 2016; 447(Supplement C): 129-40.

25. Tsuda Y, Takagi M, Wang S, Wang Z, Tang L. Movement of Aedes aegypti (Diptera: Culicidae) released in a small isolated village on Hainan Island, China. Journal of medical entomology 2001; 38(1): 93-8.

26. Liew C, Curtis CF. Horizontal and vertical dispersal of dengue vector mosquitoes, Aedes aegypti and Aedes albopictus, in Singapore. Medical and veterinary entomology 2004; 18(4): 351-60.

27. Harrington LC, Scott TW, Lerdthusnee K, et al. Dispersal of the dengue vector Aedes aegypti within and between rural communities. Am J Trop Med Hyg 2005; 72(2): 209-20.

28. Dussart P, Baril L, Petit L, et al. Clinical and virological study of dengue cases and the members of their hou seholds: the multinational DENFRAME Project. PLoS Negl Trop Dis 2012; 6(1): e1482.

29. Mutheneni SR, Mopuri R, Naish S, Gunti D, Upadhyayula SM. Spatial distribution and cluster analysis of dengue using self organizing maps in Andhra Pradesh, India, 2011-2013. Parasite Epidemiology and Control 2016.

30. Salje H, Lessler J, Endy TP, et al. Revealing the microscale spatial signature of dengue transmission and immunity in an urban population. Proceedings of the National Academy of Sciences of the United States of America 2012; 109(24): 9535-8.

31. Wearing HJ, Rohani P. Ecological and immunological determinants of dengue epidemics. Proceedings of the National Academy of Sciences of the United States of America 2006; 103(31): 11802-7.

32. Schmidt W-P, Suzuki M, Dinh Thiem V, et al. Population Density, Water Supply, and the Risk of Dengue Fever in Vietnam: Cohort Study and Spatial Analysis. PLoS Medicine 2011; 8(8): e1001082.

33. Sirisena P, Noordeen F, Kurukulasuriya H, Romesh TA, Fernando L. Effect of Climatic Factors and Population Density on the Distribution of Dengue in Sri Lanka: A GIS Based Evaluation for Prediction of Outbreaks. PLoS ONE 2017; 12(1): e0166806.

34. Silva FD, dos Santos AM, Correa Rda G, Caldas Ade J. Temporal relationship between rainfall, temperature and occurrence of dengue cases in Sao Luis, Maranhao, Brazil. Ciencia \& saude coletiva 2016; 21(2): 641-6.

35. Choi Y, Tang CS, McIver L, et al. Effects of weather factors on dengue fever incidence and implications for interventions in Cambodia. BMC Public Health 2016; 16: 241.

36. Hii YL, Zhu H, Ng N, Ng LC, Rocklöv J. Forecast of Dengue Incidence Using Temperature and Rainfall. PLoS Neglected Tropical Diseases 2012; 6(11): e1908.

37. Xu H-Y, Fu X, Lee LKH, et al. Statistical Modeling Reveals the Effect of Absolute Humidity on Dengue in Singapore. PLoS Neglected Tropical Diseases 2014; 8(5): e2805.

38. Sumi A, Telan EF, Chagan-Yasutan H, Piolo MB, Hattori T, Kobayashi N. Effect of temperature, relative humidity and rainfall on dengue fever and leptospirosis infections in Manila, the Philippines. Epidemiology and infection 2017; 145(1): 78-86

39. Cheng Q, Jing Q, Spear RC, Marshall JM, Yang Z, Gong P. Climate and the Timing of Imported Cases as Determinants of the Dengue Outbreak in Guangzhou, 2014: Evidence from a Mathematical Model. PLOS Neglected Tropical Diseases 2016; 10(2): e0004417.

40. Sang S, Gu S, Bi P, et al. Predicting Unprecedented Dengue Outbreak Using Imported Cases and Climatic Factors in Guangzhou, 2014. PLOS Neglected Tropical Diseases 2015; 9(5): e0003808. 


\section{Dengue Virus Transmission during Outbreak within Endemic Area in Indonesia : A Spatial and Temporal Analysis}

ORIGINALITY REPORT

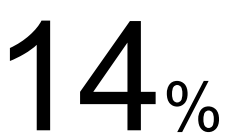

SIMILARITY INDEX

PRIMARY SOURCES

1 www.researchgate.net

Internet

82 words $-4 \%$

2 media.neliti.com

Internet

25 words $-1 \%$

3 Srinivasa Rao Mutheneni, Rajasekhar Mopuri,

Suchithra Naish, Deepak Gunti, Suryanarayana Murty

24 words $-1 \%$

Upadhyayula. "Spatial distribution and cluster analysis of dengue

using self organizing maps in Andhra Pradesh, India, 2011-2013",

Parasite Epidemiology and Control, 2018

Crossref

4 journals.plos.org

Internet

22 words $-1 \%$

5 Sang, Shaowei, Shaohua Gu, Peng Bi, Weizhong

Yang, Zhicong Yang, Lei Xu, Jun Yang, Xiaobo Liu,

20 words $-1 \%$

Tong Jiang, Haixia Wu, Cordia Chu, and Qiyong Liu. "Predicting

Unprecedented Dengue Outbreak Using Imported Cases and

Climatic Factors in Guangzhou, 2014", PLoS Neglected Tropical

Diseases, 2015.

Crossref

6 doaj.org

Internet

16 words $-1 \%$

7 PDNN Sirisena, Faseeha Noordeen, Harithra Kurukulasuriya, Thanuja ALAR Romesh, LakKumar

16 words $-1 \%$

Fernando. "Effect of Climatic Factors and Population Density on the Distribution of Dengue in Sri Lanka: A GIS Based Evaluation 
for Prediction of Outbreaks", PLOS ONE, 2017

Crossref

8 www.chess-science.com

Internet

14 words $-1 \%$

9 www.researchsquare.com

Internet

11 words $-<1 \%$

10 www.e-sciencecentral.org

Internet

11 words $-<1 \%$

11 Wolf-Peter Schmidt. "Population Density, Water Supply, and the Risk of Dengue Fever in Vietnam:

10 words $-<1 \%$ Cohort Study and Spatial Analysis", PLoS Medicine, 08/30/2011 Crossref

12 K. A. N. K. Karunarathna, J. Sriranganesan. "Impact of Climatic Factors on Dengue Incidences in Eastern

9 words $-<1 \%$ Province, Sri Lanka", International Journal of TROPICAL DISEASE \& Health, 2020

Crossref

13 Tsung-Ting Tsai, Chia-Ling Chen, Yee-Shin Lin, Chih-Peng Chang et al. "Microglia retard dengue 9 words $-<1 \%$ virus-induced acute viral encephalitis", Scientific Reports, 2016 Crossref

14 www.scirp.org Internet

8 words $-<1 \%$

15 parasitesandvectors.biomedcentral.com Internet

8 words $-<1 \%$

16 Munehisa Fukusumi, Takeshi Arashiro, Yuzo Arima, 7 words $-<1 \%$ Tamano Matsui et al. "Dengue Sentinel Traveler Surveillance: Monthly and Yearly Notification Trends among Japanese Travelers, 2006-2014", PLOS Neglected Tropical Diseases, 2016 Crossref

17 Saeed Bashirian, Shabnam Seyedzadeh-Sabounchi, 7 words $-<1 \%$ 
Samane Shirahmadi, Ali-Reza Soltanian et al. "Socio-demographic determinants as predictors of oral hygiene status and gingivitis in schoolchildren aged 7-12 years old: A cross-sectional study",

PLOS ONE, 2018

Crossref

18 eprints.manipal.edu

Internet

6 words $-<1 \%$

19 Uma Langkulsen, Kamol Promsakha $\mathrm{Na}$ Sakolnakhon, Nigel James. "Climate change and

6 words $-<1 \%$ dengue risk in central region of Thailand", International Journal of Environmental Health Research, 2019

Crossref 